\section{Scientific journal}

\section{PHYSICAL AND MATHEMATICAL EDUCATION}

Has been issued since 2013.

Науковий журнал

ФІЗИКО-МАТЕМАТИЧНА ОСВІТА

Видається з 2013.
ISSN 2413-158X (online)

ISSN 2413-1571 (print)

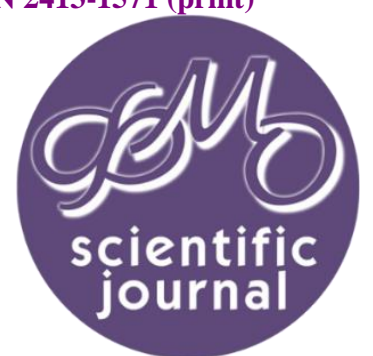

Федчишин О.М., Мохун С.В. Окремі аспекти реалізації політехнічного навчання у шкільному курсі фізики. Фізикоматематична освіта. 2021. Випуск 1(27). С. 94-99.

Fedchyshyn 0. ., Mohun S. Separate aspects of the realization of polytechnic education in the school course of physics. Physical and Mathematical Education. 2021. Issue 1(27). P. 94-99.

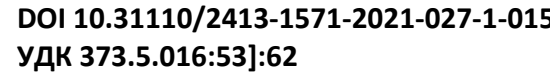

DOI 10.31110/2413-1571-2021-027-1-015

удк 373.5.016:53]:62

О.М. Федчишин

Тернопільський начіональний педагогічний університет імені Володимира Гнатюка, Україна olga.fedchishin.77@gmail.com ORCID: 0000-0003-3050-3584

C.B. Мохун

Тернопільський національний педагогічний університет імені Володимира Гнатюка, Україна mohun_sergey@ukr.net ORCID: 0000-0001-7215-6977

\title{
ОКРЕМІ АСПЕКТИ РЕАЛІЗАЦІЇ ПОЛІТЕХНІЧНОГО НАВЧАННЯ У ШКІЛЬНОМУ КУРСІ ФІЗИКИ
}

АНОТАЦІЯ

\begin{abstract}
Формулювання проблеми. У XXI столітті в Україні набули актуальності проблеми щодо підвищення практичної спрямованості шкільної освіти та оцінювання результативності навчання з позиції компетентності учнів як інтегрованого результату навчання. Суспільство потребує людей свідомих, иілеспрямованих, діяльних у побудові свого життя, соціально активних, здатних до індивідуальної творчої роботи, спрямованої на перетворення дійсності та самих себе. Сучасна молодь повинна бути готовою до використання сучасних технічних надбань цивілізації, вміти безпечно їх використовувати, бути екологічно свідомою, швидко адаптуватись у мінливому світі технологій. Освіта повинна забезпечувати адекватність потенціалу трудових ресурсів техніці, технологіям, методам управління виробництвом, які сьогодні оновлюються дуже швидко. Саме політехнічна освіта є одним із базових компонентів загальної освіти, без якого неможливий всебічний розвиток людини, а відновлення політехнічного навчання продиктоване потребами часу і має загальнодержавне значення. Тому, у статті розглянуто проблему підвищення якості шкільної фізичної освіти через реалізацію політехнічного навчання в прочесі вивчення фізики, формування в учнів технічних знань та умінь, які відповідатимуть рівню науково-технічного прогресу. Впровадження «політехнічного навчання" здійснюється як через зміст навчального матеріалу, так і через різноманітні форми й методи навчальної діяльності.

Матеріали і методи. У процесі дослідження були застосовані такі методи: теоретичні-аналіз, порівняння, систематизація та узагальнення навчально-методичних, науково-популярних та прикладних джерел з проблеми дослідження.

Результати. Розглянуто дидактичні можливості застосування технічних задач у шкільному курсі фізики як засобу реалізації політехнічного навчання, розкрито їхні функції та роль у формуванні політехнічних знань та умінь; виокремлено завдання задач технічного змісту, сформульовано вимоги до них, наведено приклади задач технічного змісту з окремих розділів фрізики, які сприяють підвищенню ефективності навчально-виховного процесу, забезпечують формування як ключових так і предметної компетентності учнів, успішне застосування знань у різних життєвих ситуаціях.

Висновки. Процес розв'язування запропонованих завдань технічного змісту забезпечує здійснення дослідницької діяльності; активізацію пізнавального інтересу учнів; інтересу до пізнання навколишнього світу та можливості експериментального вивчення фізичних процесів. Реалізація політехнічного навчання в освітньому процесі створює можливості для особистісного самовизначення та самореалізації учнів, для здійснення професійного вибору учнів відповідно до ї інтересів, здібностей, нахилів.
\end{abstract}

КЛЮчОвІ СлОвА: політехнічне навчання, політехнічна освіта, принцип політехнізму, задачі технічного змісту.

\section{ВСТУП}

Постановка проблеми. У XXI столітті в Україні набули актуальності проблеми щодо підвищення практичної спрямованості шкільної освіти та оцінювання результативності навчання з позиції компетентності учнів як інтегрованого результату навчання.

(C) О.М. Федчишин, С.В. Мохун, 2021. 
Суспільство потребує людей свідомих, цілеспрямованих, діяльних у побудові свого життя, соціально активних, здатних до індивідуальної творчої роботи спрямованої на перетворення дійсності та самих себе. Сучасна молодь повинна бути готовою до використання сучасних технічних надбань цивілізації, вміти безпечно їх використовувати, бути екологічно свідомою, швидко адаптуватись у мінливому світі технологій. Освіта повинна забезпечувати адекватність потенціалу трудових ресурсів техніці, технологіям, методам управління виробництвом, які сьогодні оновлюються дуже швидко. Саме політехнічна освіта $€$ одним із базових компонентів загальної освіти, без якого неможливий всебічний розвиток людини, а відновлення політехнічного навчання продиктоване потребами часу і має загальнодержавне значення.

Фізика, як навчальний предмет, відіграє найбільш вагому роль у реалізації політехнічного навчання. Впродовж тривалого часу сприйняття фізики як прикладної науки спотворювалось, що зумовило втрату нею конкурентоспроможності у порівнянні з суспільними науками. Це означає, що навчальний процес з фізики слід орієнтувати на формування в учнів знань і умінь, що дозволять їм у майбутньому підтримувати та розвивати науковий і технічний потенціал своєї країни. Одним із шляхів вирішення проблеми підвищення якості шкільної фізичної освіти $\epsilon$ реалізація політехнічного навчання в процесі вивчення фізики у закладах загальної середньої освіти, формування в учнів технічних знань та умінь, які відповідатимуть рівню науково-технічного прогресу.

Політехнічна освіта $є$ одним із базових компонентів загальної освіти, без якого неможливий всебічний розвиток людини. Впровадження цього компонента здійснюється як через зміст навчального матеріалу так і через різноманітні форми й методи навчальної діяльності. Однак, проблема реалізації політехнічного навчання учнів у процесі навчання фізики $€$ достатньо актуальною у галузі теорії та методики навчання фізики.

Метою статті $€$ розглянути дидактичні можливості технічних задач як засобу реалізації політехнічного навчання у закладах загальної середньої освіти та запропонувати авторські приклади задач технічного змісту для формування технічних знань та умінь учнів.

Аналіз попередніх досліджень. Велику увагу відновленню політехнічного навчання приділяв відомий український методист Є.В. Коршак. Теоретичні та практичні аспекти політехнічного навчання учнів під час навчання фізики вивчали О.І. Бугайов, Н.Т. Глазунов, С.У.Гончаренко, І.В.Ільїн, Г. Імашев, А.В. Касперський, О.І. Ляшенко, В.Г. Разумовський, В.Ф. Савченко, М. Т. Мартинюк, А.І. Павленко, А.М. Сабо, О.В. СергєєВ, В.Д. Шарко, М.І. Шут та ін. В їхньому науковому доробку на основі актуальних на той час уявлень про політехнізм розкрито структуру політехнічних знань, визначено прикладний зміст шкільного курсу фізики та методику ознайомлення учнів з найголовнішими галузями виробництва. Реалізацію принципу політехнізму через використання сучасних засобів у процесі навчання фізики у своїх наукових доробках досліджує В. П. Вовкотруб; важлива роль технічних знань у процесі навчання фізики висвітлена у працях Л.Ю. Благодаренко, політехнічна компетентність - працях В.Б. Брюховецького, Л.А. Борисова, А.А. Дробіна, О.М. Міхніна (Благодаренко, 2012). У працях А.Т. Глазунова висвітлені зміст, форми і методи роботи вчителя фізики, які складають основу політехнічної освіти і профорієнтації учнів на уроках фізики, факультативних і позаурочних заняттях. Українські науковці Н.М. Бібік, В.М. Мадзігон, Н.Г. Никало, О.Я. Савченко, В.К. Сидоренко проблему політехнізації розглядають в контексті профільного та трудового навчання.

\section{ТЕОРЕТИЧНІ ОСНОВИ ДОСЛІДЖЕННЯ}

У науковій та навчально-методичній літературі зустрічаються терміни «політехнічна освіта», «політехнічне навчання», «політехнізм». Термін «політехнічна освіта» найчастіше трактується як процес і результат засвоєння політехнічних знань, умінь, набуття особистістю політехнічних якостей, оволодіння політехнічними технологіями, розуміння та засвоєння основних закономірностей будови й функціонування техніко-технологічних систем, організаційноекономічних та соціальних аспектів сучасного виробництва, діяльності людини в системі «наука - виробництво» (Благодаренко, 2010). Політехнічна освіта - освіта, що дає знання про головні галузі й наукові принципи виробництва та озброює учнів загально-технічними уміннями, необхідними для їх участі у виробничій праці (Сіпій, 2017).

Політехнічна освіта на уроках фізики забезпечує формування як ключових, так і предметної компетентності.

Політехнічне навчання - це опанування системи знань про наукові основи сучасного виробництва, набуття навичок поводження з найуживанішими засобами праці, формування та розвиток технічних здібностей та творчого ставлення до праці. Політехнічне навчання грунтується на принципі політехнізму.

У науковій літературі часто вживається поняття «політехнізм», як система навчання, яка передбачає теоретичне і практичне ознайомлення з основними галузями сучасного виробництва (Благодаренко, 2012); принцип політехнізму один з основних принципів побудови навчально-виховної роботи в сучасній школі, що забезпечує підготовку спеціалістів широкої профілю на основі виявлення та вивчення інваріантної наукової основи, загальної для різних наук, технічних дисциплін, технологій виробництва, що дозволить учням переносити знання та уміння з однієї галузі в іншу (Сіпій, 2017).

Оскільки політехнічна освіта передбачає теоретичне та практичне ознайомлення учнів з техніко-технологічними, організаційно-економічними основами й соціально-психологічними аспектами сучасного виробництва, що забезпечує гармонійний розвиток і профорієнтацію молоді, підготовку до виконання трудових функцій та їх можливої зміни, то варто виділити актуальні завдання, які конкретизують шляхи ії реалізації:

1. Засвоєння системи політехнічних знань і вмінь, необхідних для оволодіння професіями сучасного виробництва.

2. Професійна орієнтація учнів, необхідна для свідомого вибору ними професії, що відповідає їх бажанням, можливостям і потребам суспільства.

3. Розвиток розумових і технічних здібностей, здатності до перенесення набутих знань та вмінь в нові умови діяльності.

Завдання політехнічної освіти учнів вирішуються комплексом навчальних предметів, але особлива роль належить саме фізиці, як науці, що визначає розвиток техніки. 3 одного боку, фізика - це фундамент техніки, з іншого боку, техніка стимулює наукові дослідження, дає нові технічні засоби для фізичних досліджень. 
Основними методами та формами реалізації політехнічного навчання на уроках фізики є: пояснення прикладів застосування фізичних явищ і законів; фізико-технічні лабораторні роботи; демонстрації дослідів на моделях і макетах; розв'язування задач з технічним і технологічним змістом; проведення екскурсій на виробництво; залучення учнів у фізикотехнічні гуртки; демонстрація фільмів політехнічного змісту; читання науково-технічної літератури (Федчишин\&Мохун, 2020). Також цьому сприяють виконання завдань експериментального характеру, виконання проєктів політехнічного змісту тощо.

Детальніше зупинимось на задачах технічного змісту, які мають значні дидактичні можливості для реалізації основних завдань політехнічного навчання на уроках фізики. Задачний підхід - важлива складова навчально-пізнавальної діяльності при вивченні фізики, а також, на сьогодні, провідна форма зовнішнього незалежного оцінювання. В освітніх навчальних програмах з фізики визначено, що «...без розв'язування задач шкільний курс фізики не може бути засвоєний».

Основними завданнями, що ставляться перед задачами технічного змісту $є$ :

- ознайомити учнів із основами сучасного виробництва, провідними напрямами науково-технічного прогресу; продемонструвати вплив фізики на розвиток технологій, нових напрямів підприємництва; спонукати учнів до вміння аналізувати причинно-наслідкові зв'язки, прогнозувати роль наукових досягнень;

- навчити використовувати знання з фізики для вирішення завдань, пов'язаних із реальними об'єктами природи i техніки, матеріальними й енергетичними ресурсами; для генерування ідей та ініціатив щодо проектної, конструкторської та винахідницької діяльності;

- враховуючи вікові особливості учнів формувати ціннісне ставлення до системи «людина-техніка», ознайомлювати з методами пізнання природи, виявляти конструкторські, комунікативні, дослідницькі та інші здібності учнів;

- формувати вміння оцінювати власні здібності щодо вибору майбутньої професії, ії зв'язок з фізикою чи технікою, можливість застосування набутих знань з фізики в майбутній професійній діяльності, для ефективного вирішення повсякденних проблем.

Як свідчить аналіз підручників з фізики для учнів 10-11 класу (Бар'яхтар, 2011; Бар'яхтар, 2018; Засєкіна, 2018), відсоток технічних задач у них надто низький. Задачі, які представлені у підручниках (Бар'яхтар, 2011; Бар'яхтар, 2018; Засєкіна, 2018) мають, як правило, абстрактний характер й однакову структуру; не відповідають комптентнісній парадигмі навчання, більшість завдань, спрямовані на тренування учня в алгебраїчних й арифметичних операціях; застосовуються для перевірки і закріплення знань в практиці навчання фізики. Розв'язування стереотипних задач не завжди дозволяє забезпечити реалізацію основних аспектів політехнічної освіти.

Тому важливо підібрати такі задачі, які 6 сприяли досягненню заданих педагогічних цілей, а головна увага була 6 спрямована на усвідомлення важливості формування технічних знань та умінь на уроках фізики. Розв'язуючи задачі технічного змісту учні усвідомлюють основи фізичної науки, засвоюють основні поняття й закони, оцінюють роль знань в житті людини і суспільному розвитку, а також формується науковий світогляд і відповідний стиль мислення, розвиток здатності пояснювати природні явища і процеси та застосовувати здобуті знання під час розв'язування задач, удосконалення досвіду провадження експериментальної діяльності.

Для формування політехнічних знань важливо добирати задачі пов'язані із явищами, які учні спостерігають у реальному житті, які мають профорієнтаційне спрямування та є важливими для вибору майбутньої професії, тобто необхідність політехнічної освіти обумовлена ситуацією на ринку праці, де не вистачає висококваліфікованих технічних спеціалістів.

\section{МЕТОДИ ДОСЛІДЖЕННЯ}

У процесі дослідження були застосовані такі методи: теоретичні - аналіз, порівняння, систематизація та узагальнення навчально-методичних, науково-популярних та прикладних джерел з проблеми дослідження.

\section{РЕЗУЛЬТАТИ ДОСЛІДЖЕННЯ}

Формування в учнів технічних знань та мислення при вивченні курсу фізики забезпечить використання технічних задач.

Під технічною задачею ми розуміємо задачу з проблемним актуальним змістом, що вимагає застосування фізичних знань для пояснення роботи або будови механізмів, приладів та технічних установок, і у процесі розв'язання якої формуються дослідницько-пошукові навики, а також фізичне та технічне мислення.

Важливим $є$ підібрати такі задачі, які сприятимуть активізації пізнавального інтересу учнів. Для цього достатньо виконання наступних умов:

- задачі мають бути зрозумілими для учнів, привертати увагу своєю практичною значущістю;

- задачі містять інформацію про явища та процеси, які учні достатньо часто спостерігають у повсякденному житті.

Зауважимо, що до технічних задач $є$ певні вимоги:

- задачі повинні відповідати освітній програмі, меті та завданням при вивченні конкретної теми;

- поняття та терміни повинні бути максимально наближеними до загальноприйнятих у техніці та технологіях;

- методи розв'язування задач повинні бути наближеними до практичних прийомів і методів.

Для розуміння сутності технічних задач, наведемо авторські приклади таких завдань з окремих розділів фізики.

Задача 1. Експлуатація високошвидкісних потягів на постійній основі практикується у багатьох країнах, зокрема Німеччині, Італії, Японії, Іспанії, Франції, Кореї, Китаї тощо. Такі потяги розвивають швидкість 250-400 км/год.

1.1. Від яких технічних параметрів залежить максимальна швидкість високошвидкісного потягу?

1.2. Що Вам відомо про експлуатацію високошвидкісних потягів в Україні? 
Відповідь. Високошвидкісні залізниці є сучасним індикатором якості життя й комунікаційних можливостей держави, а також показником ї̈ технічного потенціалу в цілому.

1.1. Поняття «високошвидкісна залізниця» сформувалось після запуску в експлуатацію в 1964 р. першої у світ спеціалізованої залізничної магістралі Токіо-Осака в Японії (швидкість потяга становила $210 \mathrm{~km} /$ год).

Максимальна швидкість швидкісного (високошвидкісного) поїзда залежить від таких основних технічних параметрів: загальної маси поїзда; потужності тягових електродвигунів; частки моторних осей і їх розподілу по довжині поїзда (зосередження на локомотиві або розподіл по моторних вагонах); пасажиромісткості вагонів; опору руху поїзда (у тому числі пов'язаного з аеродинамічними характеристиками).

1.2. В Україні поїзди Інтерсіті й Інтерсіті+ з'явилися завдяки підготовці країни до чемпіонату ЄВРО-2012, незважаючи на те, що українська залізниця планувала впровадження швидкісних поїздів такого класу ще на початку минулого десятиліття. Оскільки у 2007 р. стало відомо, що Україна прийме футбольні матчі ЄВРО-2012, розвиток швидкісного руху поїздів було включено в стратегічний план підготовки саме до цього чемпіонату. На початку грудня 2010 p. з південнокорейською фірмою Hyundai Rotem Corporation був підписаний договір про постачання і на початку грудня 2011 р. відбулася передача першого поїзду українським залізничникам, який стали називати Інтерсіті+. Такий потяг призначений для перевезення пасажирів на електрифікованих ділянках залізниць із номінальною напругою в контактній мережі 25 кВ змінного струму з частотою 50 Гц та 3 кВ постійного струму. Експлуатаційна швидкість електропоїзда складає $160 \mathrm{kм} /$ год.

Звичайно, щоб успішно розв'язати таку задачу, учні повинні опрацювати додаткові джерела інформації. У процесі вони ознайомлюються з технічними характеристиками транспортного засобу, його технічними можливостями, 3 технічними характеристиками високошвидкісної залізниці, чим вони відрізняються у різних країнах світу, вивчають нові поняття, наприклад експлуатаційна та конструкційна швидкості тощо.

Задача 2. Експериментальні поїзди на магнітній підвісці в Німеччині та Японії розвивали швидкість до 400 км/год, у Китаї на сьогодні презентували потяг, що розвиває швидкість до 600 км/год. Потяги на магнітній підвісці ніби «пливуть» над рейсами (рис.1 а, 1 б). Поясніть це.

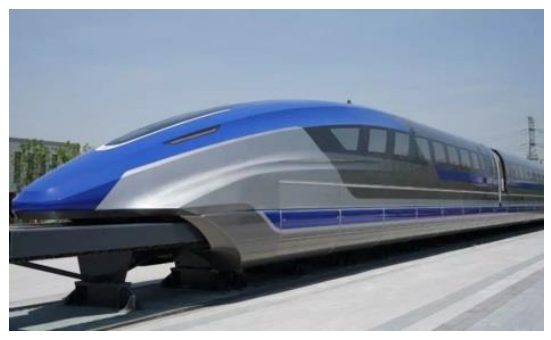

а) Маглев (Китай)

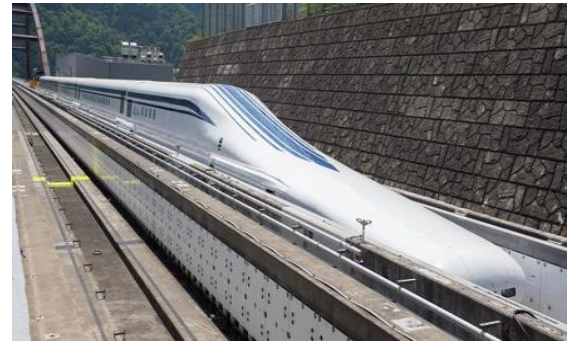

б) Маглев (Японія)

Рис. 1. Магнітоплани

Відповідь. Потяги на магнітних підвісах рухаються та керуються за допомогою магнітних сил і називаються магнітопланами або "маглев». Поля створюються струмом, який проходить по обмотках електромагнітів, розміщених вздовж рейки та під поїздом. Так як, однойменні полюси відштовхуються, то потяг рухається в сильному магнітному полі. Під час руху такі потяги зазнають значно меншого тертя, ніж звичайні; менше зношуються деталі (Тейлор, 2005).

Задачі такого типу вчитель завжди може доповнити додатковими запитаннями, наприклад:

1. Для чого призначені гальмові пристрої на високошвидкісних поїздах?

2. Які види гальмувань застосовують під час руху високошвидкісного поїзда?

3. Назвіть переваги та недоліки маглев.

4. Чи можливе створення такого виду транспорту в Україні?

Цікавими для реалізації політехнічного навчання учнів $€$ технічні задачі, які містять неповну інформацію і сформульовані таким чином, що для їх розв'язання необхідно використовувати довідкову літературу, паспортні дані машин, приладів та пристроїв; ілюстровані рисунками, схемами, що дозволяють отримати інформацію, якої не вистачає. Крім того, учні самостійно можуть проектувати задачі технічного змісту.

\section{ОБГОВОРЕННЯ}

Розв'язування технічних задач забезпечує якісніше засвоєння знань, завдяки виникненню асоціацій з конкретними явищами та процесами; спрямованості на застосування фізичних законів у техніці, промисловості, сільськогосподарському виробництві, транспорті, енергетиці, тощо. Технічні задачі у навчальному процесі використовуються з різною дидактичною метою: для розвитку розумової діяльності, активізації інтересу до вивчення фізики, здійснення міжпредметної інтеграції знань, формування практичних умінь.

У навчальному процесі з фізики вони виконують функції: навчальну; розвиваючу; виховну; мотиваційну; прогностичну; інтегративну; контролюючу. Зазначені функції мають загальний характер і притаманні всім фізичним задачам.

Розв'язування фізичних задач $є$ також «...засобом усвідомлення й засвоєння досліджуваних понять, явищ $і$ закономірностей, створення проблемних ситуацій, методом вдосконалення знань і способом формування логікоаналітичних умінь, встановлення зв'язку курсу фізики з життєвими явищами і виробничими процесами» (Мельник\&Сіпій, 2018). У практиці навчально-виховної діяльності технічні задачі використовуються як засіб набуття практичних умінь (експериментування, конструювання, моделювання), навичок професійного самовизначення, реалізації принципу 
політехнізму, екологічного й економічного виховання. Розв'язуючи подібні задачі, учні здобувають знання, необхідні для продовження освіти у вищих навчальних закладах фізико-математичного, природничого й технологічного спрямування.

Задачний підхід до формування предметної компетентності дає змогу розвивати пізнавальні інтереси, відповідний стиль мислення, інтелектуальні й пошуково-творчі здібності, активізувати навчально-пізнавальну діяльність учнів, ознайомлювати їх з методами наукового дослідження. Самостійне розв'язування таких задач учнями розвиває їхню активність у здобуванні знань, уміння і навички, їхні творчі здібності. У деяких задачах учні цілком самостійно конструюють мислено, а потім реалізують на практиці різноманітні установки і пристрої (Федчишин\&Мохун, 2018).

\section{вИСНОВкИ}

Сьогодні в основній та старшій школах під час вивчення фізики помітний нахил робиться у бік теорії, яка не викликає в учнів інтересу до засвоєння питань технічного змісту, а, отже, й фізичних явищ, які лежать в основі тих чи інших технічних пристроїв. Більшості учнів здається, що фізика як наука сьогодні не є потрібною для їх повсякденного життя. Тому, чим ефективніше реалізується принцип політехнізму в освітньому процесі, тим більше можливостей для особистісного самовизначення та самореалізації учнів, для здійснення професійного вибору учнів відповідно до їх інтересів, здібностей, нахилів.

Отже, у більшості закладів загальної середньої освіти використання на уроках фізики матеріалу політехнічного змісту може стати єдиним засобом популяризації фізичної науки, що вкрай необхідно. Учитель фізики повинен використати всі можливості для того, щоб учні чітко розуміли - без фізики і техніки суспільство існувати не може.

\section{Список використаних джерел}

1. Бар'яхтар В. Г., Довгий С. О., Божинова Ф. Я., Кірюхіна О. О. Фізика. 11 клас. Академічний рівень. Профрільний рівень: підруч. для загальноосвітн. навч. закл. Харків : Вид-во «Ранок», 2011. 320 с.

2. Бар'яхтар В. Г., Довгий С. О., Божинова Ф. Я., Кірюхіна О. О. Фізика (рівень стандарту, за навчальною програмою авторського колективу під керівництвом Локтєва В. М.): підруч. для 10 кл. закл. загал. серед. освіти. Харків : Видво «Ранок», 2018. 272 с.

3. Благодаренко Л. Ю. Інноваційні підходи до концепції розвитку політехнічного навчання в основній школі. Збірник наукових праць Кам'янець-Подільського національного університету імені Івана Огієнка. Серія педагогічна. Кам'янець-Подільський, 2010. Вип. 16. С. 265-268.

4. Благодаренко Л. Ю., Шут М.І. Сучасні підходи до політехнізації навчання фізики та перспективи ї̈ відновлення. Науковий часопис Національного педагогічного університету імені М.П. Драгоманова. Серія 5: Педагогічні науки: реалії та перспективи : збірник наукових праць. Київ, 2012. Вип. 32. С. 30-35.

5. Велика ілюстрована енциклопедія ерудита: Пер. з англ./ Наук. кер. авт. колективу Ч. Тейлор. К: Махаон-Україна, 2005. 496с. іл.

6. Засєкіна Т. М., Засєкін Д.О. Фізика (профільний рівень) : підруч. для 10 кл. закл. загал. серед. освіти. Київ : УОВц «Оріон», 2018. 304 c.

7. Мельник Ю. С., Сіпій В.В. Формування предметної компетентності старшокласників у процесі навчання фізики. К:ТОВ «КОНВІ ПРІНТ», 2018. 136 c.

8. Сіпій В.В. Вплив політехнічного складника предметної компетентності з фізики на професійне самовизначення школярів. Наукові записки РДГУ. Рівне, 2017. Вип. 17. С. 141-145.

9. Федчишин О.М., Мохун С. В. Методичні можливості застосування експериментальних задач для розвитку винахідницької та дослідницької діяльності учнів. Збірник наукових праць Кам'янець-Подільського національного університету імені Івана Огієнка. Серія педагогічна. Кам'янець-Подільський, 2018. Вип. 24. С. 84-87.

10. Федчишин О. М., Мохун С. В. Політехнічне навчання у формуванні предметної компетентності учнів на уроках фізики. Підготовка майбутніх учителів фізики хімії біології та природничих наук в контексті вимог Нової української школи : зб. тез доп. II міжнар. наук.-практ. конф., м. Тернопіль, 14 травня 2020 р. Тернопіль, 2020. С. 40-43.

11. Фізика. Навчальні програми для загальноосвітніх навчальних закладів. Фізика. 10-11 класи. URL: https://mon.gov.ua/storage/app/media/zagalna\%20serednya/programy-10-11-klas/2018-2019/fizika-10-11-avtorskijkolektiv-pid-kerivnicztvom-lokteva-vm.pdf. (дата звернення 27.01.2021).

12. Шерстюк С.О. Задачі технічного змісту у навчанні фізики як засіб формування в учнів здатності до наукового пізнання. Збірник наукових праць Кам'янець-Подільського національного університету імені Івана Огієнка. Серія педагогічна. Кам'янець-Подільський, 2016. Вип. 22. С. 239-241.

\section{References}

1. Bariakhtar, V. H., Dovhyi, S. O., Bozhynova, F. Ya. \& Kiriukhina, O. O. (2011). Fizyka. 11 klas. Akademichnyy riven. Profilnyy riven: pidruch. dlia zahalnoosvitn. navch. zakl. [Physics. Grade 11. Academic level. Profile level. The textbook for secondary schools] Kharkiv : Vyd-vo «Ranok» [in Ukraine].

2. Bariakhtar, V. H., Dovhyi, S. O., Bozhynova, F. Ya. \& Kiriukhina, O. O. (2018). Fizyka (riven standartu, za navchalnoiu prohramoiu avtorskoho kolektyvu pid kerivnytstvom Loktieva V. M.) : pidruch. dlia 10 kl. zakl. zahal. sered. osvity. [Physics (standard level, under the curriculum of the authors' team under the direction of V.M. Loktev)] Kharkiv : Vyd-vo «Ranok» [in Ukraine].

3. Blahodarenko, L. Yu. (2010). Innovatsiini pidkhody do kontseptsii rozvytku politekhnichnoho navchannia v osnovnii shkoli. [Innovative approaches to the concept of development of polytechnic education in primary school]. Zbirnyk naukovykh prats Kamianets-Podilskoho natsionalnoho universytetu imeni Ivana Ohiienka. Seriia pedahohichna. Kamianets-Podilskyi Collection of scientific works of Kamianets-Podilskyi National University named after Ivan Ogienko. The series is pedagogical, (16). 265-268 [in Ukraine]. 
4. Blahodarenko, L. Yu. \& Shut, M. I. (2012). Suchasni pidkhody do politekhnizatsii navchannia fizyky ta perspektyvy yii vidnovlennia. [Modern approaches to polytechnic teaching of physics and prospects for its restoration]. Naukovyy chasopys Natsional'noho pedahohichnoho universytetu imeni M.P. Drahomanova. Seriia 5: Pedahohichni nauky: realii ta perspektyvy Scientific journal of the National Pedagogical University named after M. Dragomanov. Series 5: Pedagogical sciences: realities and prospects, 32, 30-35 [in Ukrainian].

5. Teilor, Ch. (2005). Velyka iliustrovana entsyklopediia erudyta [Large illustrated encyclopedia of erudite].- Kyiv: Makhaon [in Ukraine].

6. Zasiekina, T.M. \& Zasiekin, D.O. (2018). Fizyka (profilnyi riven) : pidruch. dlia $10 \mathrm{kl}$. zakladiv zahalnoi serednoi osvity. [Physics (profile level): textbook. for 10 cells. institutions of general secondary education]. Kyiv : UOVTs «Orion» [in Ukraine].

7. Melnyk, Yu. S. \& Sipii, V. V. (2018). Formuvannia predmetnoi kompetentnosti starshoklasnykiv u protsesi navchannia fizyky. [Formation of subject competence of high school students in the process of teaching physics]. - K:TOV «KONVI PRINT» [in Ukrainian].

8. Sipii V. V. (2017). Vplyv politekhnichnoho skladnyka predmetnoi kompetentnosti z fizyky na profesiine samovyznachennia shkoliariv [The influence of the polytechnic component of subject competence in physics on the professional selfdetermination of students]. Naukovi zapysky RDHU. - Scientific notes of RDHU, (17), Rivne, 141-145 [in Ukraine].

9. Fedchyshyn, O. M. \& Mokhun, S. V. (2018). Metodychni mozhlyvosti zastosuvannia eksperymentalnykh zadach dlia rozvytku vynakhidnytskoi ta doslidnytskoi diialnosti uchniv [Methodical possibilities of application of experimental problems for development of inventive and research activity of pupils]. Zbirnyk naukovykh prats Kamianets-Podilskoho natsionalnoho universytetu imeni Ivana Ohiienka. Seriia pedahohichna. Kamianets-Podilskyi, 24. 84-87 [in Ukrainian].

10. Fedchyshyn, O. M. \& Mokhun, S. V. (2020). Politekhnichne navchannia u formuvanni predmetnoi kompetentnosti uchniv na urokakh fizyky. [Polytechnic education in the formation of subject competence of students in physics lessons.] Pidhotovka maibutnikh uchyteliv fizyky khimii biolohii ta pryrodnychykh nauk v konteksti vymoh Novoi ukrainskoi shkoly : zb. tez dop. II mizhnar. nauk.-prakt. konf. - Training of future teachers of physics, chemistry, biology and natural sciences in the context of the requirements of the New Ukrainian school: coll. thesis add. II International scientific-practical conf. (pp. 40-43). Ternopil. [in Ukrainian].

11. Fizyka. Navchalni prohramy dlia zahalnoosvitnikh navchalnykh zakladiv. Fizyka. 10-11 klasy. [Physics. Educational programs for general educational institutions. Physics. Grades 10-11] (n.d.) mon.gov.ua Retrieved from https://mon.gov.ua/storage/app/media/zagalna\%20serednya/programy-10-11-klas/2018-2019/fizika-10-11-avtorskijkolektiv-pid-kerivnicztvom-lokteva-vm.pdf [in Ukrainian].

12. Sherstiuk, S. O. (2016). Zadachi tekhnichnoho zmistu u navchanni fizyky yak zasib formuvannia $v$ uchniv zdatnosti do naukovoho piznannia. [Problems of technical content in teaching physics as a means of forming students' ability to scientific knowledge.] Zbirnyk naukovykh prats Kamianets-Podilskoho natsionalnoho universytetu imeni Ivana Ohiienka. Seriia pedahohichna. Kamianets-Podilskyi - Collection of scientific works of Kamianets-Podilskyi National University named after Ivan Ogienko. The series is pedagogical, (22). 239-241 [in Ukrainian].

\section{SEPARATE ASPECTS OF THE REALIZATION OF POLYTECHNIC EDUCATION IN THE SCHOOL COURSE OF PHYSICS O. Fedchyshyn, S. Mohun}

Ternopil Volodymyr Hnatiuk National Pedagogical University, Ukraine

Abstract. Formulation of the problem. In the XXI century in Ukraine the problems of increasing the practical orientation of school education and assessing the effectiveness of learning from the standpoint of student competence as an integrated learning outcome have become relevant. Society needs people who are conscious, purposeful, active in building their lives, socially active, capable of individual creative work and aimed at transforming reality and themselves. Modern youth must be ready to use the modern technical achievements of civilization, be able to use them safely, be environmentally conscious, adapt quickly to the changing world of technology. Education must ensure the adequacy of the potential of human resources to equipment, technologies, methods of production management, which today are updated very quickly. Polytechnic education is one of the basic components of general education, without which comprehensive human development is impossible, and the resumption of polytechnic education is dictated by the needs of the time and has nationwide importance. Therefore, the article considers the problem of improving the quality of school physics education through the implementation of polytechnic education in the study of physics, the formation of students technical knowledge and skills that will correspond to the level of scientific and technological progress. The introduction of "polytechnic education" is carried out both through the content of educational material and through various forms and methods of educational activities.

Materials and methods. The following methods were used in the research process: theoretical - analysis, comparison, systematization and generalization of educational and methodical, popular science and applied sources on the research problem.

Results. Didactic possibilities of application of technical tasks in a school course of physics as means of realization of polytechnic training are considered, their functions and a role in formation of polytechnic knowledge and abilities are explained; the tasks of technical content tasks are singled out, the requirements to them are formulated, examples of technical content tasks from separate sections of physics which promote increase of efficiency of educational process, provide formation of both key and subject competence of pupils, successful application of knowledge in various life situations are given.

Conclusions. The process of solving the proposed tasks of technical content provides the implementation of research activities; activation of students' cognitive interest; interest in learning about the world around and the possibility of experimental study of physical processes. The implementation of polytechnic education in the educational process creates opportunities for personal self determination and self-realization of students, for the professional choice of students in accordance with their interests, abilities, passions.

Keywords: Polytechnic education, polytechnic study, the principle of polytechnics, tasks of technical content 